\title{
Палий А.Ю. \\ Научно-теоретический анализ противоречий о целях деятельности организованных преступных сообществ, содержащихся в действующем уголовном законодательстве, и пути их преодоления: по материалам Республики Крым
}

\author{
Судья Верховного Суда Республики Крым
}

(Россия)

doi: $10.18411 / \mathrm{sr}-10-08-2017-11$

idsp: 000001:sr-10-08-2017-11

Все чаще на международном законодательном уровне находят свое отражение упоминания о необходимости противодействия различным формам организованной преступности, ввиду того, что данное преступное явление признается одной из основных угроз полноценного функционирования и развития современного общества. Соответственно, вышесказанное позволяет утверждать, чтосовременная организованная преступность, представляя собой достаточно серьёзную угрозу для общества, позволяет поставить её в один ряд с угрозами национальной безопасности России. В связи с расширением масштабов организованной преступности и усилением степени общественной опасности, исходящей от данной формы преступного явления, в Уголовный кодекс Российской Федерации за последние несколько лет были внесены соответствующие изменения и дополнения как в Общую, так и в Особенную его части.

Неоднократно в научной литературе предлагалось внести изменения в Уголовный кодекс РФ, дополнив его статьей, содержащей понятие организованной преступной деятельности. В проекте закона «О борьбе с организованной преступностью» содержалась дефиниция преступной деятельности как «системы деяний с заранее обдуманным умыслом по приготовлению, покушению, совершению одного или более преступлений, предусмотренных статьями Особенной части Уголовного кодекса РСФСР или настоящим Федеральным законом, а также по легализации и приумножению преступных доходов, созданию иных благоприятных условий для совершения преступлений». Разными группами разработчиков аналогичные предложения по принятию Федерального закона «О борьбе с организованной преступностью» вносились на рассмотрение в Государственную Думу РФ в 1995, 1997, 2006 годах, но по разным причинам данные проекты так и не вступили в законную силу.

При этом, необходимость разработки и принятия данного нормативного правового акта в настоящее время подтверждается потребностями теории и практики противодействия преступлениям, совершаемым организованными преступными сообществами. Так, 74 \% из числа опрошенных сотрудников правоохранительных органов считают необходимым условием повышения эффективности деятельности по расследованию и раскрытию преступлений, совершенных организованными преступными сообществами на территории Республики Крым, разработку и принятие на федеральном уровне единого нормативного правового акта, регламентирующего вопросы противодействия организованной преступности в Российской Федерации (на примере Федерального закона «О противодействии терроризму», Федерального закона «О противодействии экстремистской деятельности»). Кроме того, $39 \%$ респондентов высказались в пользу необходимости дополнения статьи 35 Уголовного кодекса РФ понятием организованной преступности с указанием целей совершения данных преступлений.

Это объясняется тем, что одной из криминалистически значимых проблем, возникающих в ходе расследования рассматриваемой категории преступлений, по мнению практических работников (отметили 68\% участников опроса), является установление целей и мотивов совершения преступлений организованными преступными 
сообществами на территории Республики Крым в качестве обстоятельств, подлежащих доказыванию. При этом анализ изучения материалов уголовных дел данной категории, рассмотренных судами Республики Крым в период с апреля 2014 по июль 2017 года, свидетельствует о том, что в $96 \%$ случаев в материалах уголовных дел содержались подтвержденные сведения об установлении целей преступной деятельности организованных преступных сообществ.

В данном случае наглядно проявляется существенное противоречие, допущенное законодателем при формулировании диспозиции статьи 210 Уголовного кодекса РФ, в части несогласованности отраженных в ней целей создания (руководства, координации и т.д.): «Создание преступного сообщества (преступной организации) в целях совместного совершения одного или нескольких тяжких или особо тяжких преступлений...». При этом статья 35 Общей части Уголовного кодекса РФ в качестве целей преступной деятельности преступных сообществ указывает на то, что «...члены которых объединены в целях совместного совершения одного или нескольких тяжких либо особо тяжких преступлений для получения прямо или косвенно финансовой или иной материальной выгоды». В связи с чем следует согласиться с мнением Н.Ф. Кузнецовой и И.М. Тяжковой: «Данный признак не является безупречным, хотя бы уже в силу того, что определять качество преступного образования через тяжесть совершенного его участниками преступления некорректно, поскольку по данному признаку формирование не может быть квалифицировано как преступное сообщество. Группа лиц по предварительному сговору и организованная группа также могут создаваться для совершения тяжких и особо тяжких преступлений, ибо никаких запретов по этому поводу закон не содержит. Следовательно, создается возможность либо неоправданного сужения понятия организованной группы, либо, наоборот, необоснованной оценки случаев совершения организованной группой тяжких или особо тяжких преступлений как выполненных преступным сообществом».

Важно отметить, что включая в 2013 г. в Уголовный кодекс РФ статьи 205.4 («Организация террористического сообщества и участие в нем») и 205.5 («Организация деятельности террористической организации и участие в деятельности такой организации»), законодатель не учел уже существующее положение ст. 35, которое содержит указание на цель преступного сообщества (преступной организации) получение прямо или косвенно финансовой или иной материальной выгоды.Данная норма, безусловно, не соотносится с целью преступлений, предусмотренных в ст. 205.4 и 205.5 Уголовного кодекса РФ, поскольку террористические сообщества (организации) не обязательно и не всегда преследуют материальную или финансовую выгоду, что является особо важным обстоятельством, подлежащим доказыванию, с криминалистической и процессуальной точек зрения.

При этом важно отметить, что Постановление Пленума Верховного Суда РФ от 10 июня 2010 г. № $12 « 0$ судебной практике рассмотрения уголовных дел об организации преступного сообщества (преступной организации) или участии в нем (ней)» разъясняет, что «...что организованная преступность в ее различных проявлениях посягает на общественную безопасность, жизнь и здоровье граждан, собственность, нарушает нормальное функционирование государственных, коммерческих и иных организаций и общественных объединений».

Ярким примером совершения преступлений организованными преступными сообществами без преследования целей извлечения материальной выгоды являются преступления террористической, экстремистской направленности, совершенные исключительно в целях устрашения населения, дестабилизации функционирования органов государственного управления, разжигания вооруженных конфликтов, преследования религиозных целей и пр. Соответственно, положения как Общей, так и Особенной частей Уголовного кодекса РФ, отражающих особенности совершения 
преступлений организованными преступными сообществами, находятся в противоречии друг с другом и с объективной реальностью.

В связи с тем, что в настоящее время в юридической науке существует многообразие подходов к теоретическому определению организованной преступности, но отсутствует нормативное закрепление данного определения, представляется целесообразным дополнить часть 4 статьи 35 Уголовного кодекса РФ определением следующего содержания: «Преступление признается совершенным преступным сообществом (преступной организацией), если оно совершено структурированной организованной группой или объединением организованных групп, действующих под единым руководством, члены которых объединены в целях совместного совершения одного или нескольких тяжких либо особо тяжких преступлений для получения прямо или косвенно финансовой или иной материальной выгоды, а равно в целях посягательств на общественную безопасность и общественный порядок, жизнь и здоровье граждан, основы государственной власти, мир и безопасность человечества».

Анализ действующих нормативных правовых актов на федеральном и международном уровнях убедительно доказал, что в настоящее время при всем разнообразии определений организованной преступности отсутствует нормативное закрепление данного понятия. Так, Конвенция против транснациональной организованной преступности, а так же три протокола, принятые в дополнение к ней, при всем многообразии применяемых понятий, не содержат определения организованной преступности.

С учетом выявленных ранее учеными-правоведами особенностей организованной преступности в целом, и преступлений, совершаемых организованными преступными сообществами в частности (в том числе, на территории Республики Крым), целесообразно нормативно определить и закрепить в проекте Федерального закона «О противодействии организованной преступности» понятие организованной преступности в следующей редакции: «Организованная преступность - это системно связанная совокупность преступлений, совершаемых участниками устойчивых, иерархизированных, планомерно действующих преступных структур, деятельность которых согласуется, будучи направлена на извлечение максимальной прибыли из преступного бизнеса, на определенной территории или в определенной сфере, взятой под контроль в целях получения прямо или косвенно финансовой или иной материальной выгоды, а равно в целях посягательств на общественную безопасность и общественный порядок, жизнь и здоровье граждан, основы государственной власти, мир и безопасность человечества».

Часть 5 статьи 35 Уголовного кодекса РФ говорит о том, что лицо, создавшее организованную группу или преступное сообщество (преступную организацию) либо руководившее ими, подлежит уголовной ответственности за их организацию и руководство ими в случаях, предусмотренных статьями 205.4, 208, 209, 210 и 282.1 Кодекса, а также за все совершенные организованной группой или преступным сообществом (преступной организацией) преступления, если они охватывались его умыслом. Аналогичная формулировка относится и к иным участникам преступного сообщества. Результаты проведенного анализа и обобщения оперативной, следственной и судебной практики по рассматриваемой категории дел наглядно свидетельствует о том, что перечисленные законодателем в ч.5 статьи 35 статьи Особенной части кодекса в полной мере не отражают конкретные формы преступной деятельность организованных преступных сообществ, поскольку преступными сообществами совершаются и иные преступления, совершение которых возможно в данной организованной преступной форме, в том числе исходя из целей создания и деятельности конкретного преступного сообщества. В связи с чем представляется, что перечисление в ч. 5 статьи 35 Уголовного кодекса РФ конкретных составов преступлений, предусмотренных Особенной частью 
Уголовного кодекса, излишне ввиду многообразия целей деятельности организованных преступных сообществ и форм осуществления их деятельности.

Одним из наиболее важных направлений повышения эффективности противодействия организованным формам преступной деятельности является их правильное и четкое отграничение. В настоящее время Уголовный кодекс РФ, наряду со ст. 210, содержит семь статей, предусматривающих ответственность за деятельность различных конкретных разновидностей организованных групп (ст. 205.4, 205.5, 208, 209, $239,282.1,282.2)$, что актуализирует на практике вопрос об их конкуренции друг с другом. Говоря о соотношении организации преступного сообщества (преступной организации) или участия в нем (ней) со смежными составами преступлений, следует акцентировать внимание на выявлении их общих и отличительных криминалистически значимых признаков.

При этом, при рассмотрении наиболее общей по отношению к иным составам статья 210 Уголовного кодекса РФ «Организация преступного сообщества (преступной организации) или участие в нем (ней)» в сравнении со статьей 208 «Организация незаконного вооруженного формирования или участие в нем», можно заключить, что преступление, предусмотренное статье 210 отличается прежде всего направленностью деятельности (совершение тяжких или особо тяжких преступлений), а также возможным отсутствием оружия у членов преступного сообщества. От бандитизма анализируемое преступление отличается отсутствием обязательной цели нападения на граждан или организации, а также возможным отсутствием оружия. На основании результатов изучения уголовных дел достоверно известно, что преступное сообщество нередко создается для занятия контрабандой, торговлей наркотиками, фальшивомонетничеством, хищением чужого имущества в крупных размерах и т.п.

Кроме того, в статье 208 УК РФ говорится о таком вооруженном формировании, которое не предусмотрено федеральным законом. В ст. 1 Федерального закона от 31 мая 1996 г. № 61-Ф3 «Об обороне» сказано, что запрещаются и преследуются по закону создание и существование формирований, имеющих военную организацию или вооружение и военную технику либо в которых предусматривается прохождение военной службы, не предусмотренных федеральными законами.Таким образом, отличительным признаком незаконного вооруженного формирования является, прежде всего, то, что оно представляет собой разновидность военного формирования и совершается с целью осуществления задач военного характера. Эти цели могут быть и общественно полезны в представлении какой-то определенной группы лиц, они могут создаваться с целью защиты населения от возможных боевых или иных провокационных проявлений экстремистски настроенных групп, но главная их противозаконность заключается в том, что они созданы вопреки положениям Закона «Об обороне».

В основу разграничения двух анализируемых преступлений с криминалистической и процессуальной точек зрения должна быть положена прежде всего цель их создания. Преступное сообщество (преступная организация) всегда создается с противоправной целью для совершения тяжких и особо тяжких преступлений для получения прямо или косвенно финансовой или иной материальной выгоды. Организация незаконного вооруженного формирования преследует иные цели: политические, социально-бытовые (например: защитить город или населенный пункт от криминальных посягательств), националистические и др.

Одним из наиболее важных на протяжении многих лет остается соотношение преступлений, предусмотренных ст. 210 и ст. 209 (бандитизм) Уголовного кодекса РФ. Традиционно банда считается самой опасной разновидностью организованной группы, хотя некоторые ученые относят ее к числу преступных сообществ. По мнению С.В. Расторопова, нацеленность на совершение нападений на граждан или организации отличает бандитизм от преступлений, предусмотренных ст. 208 и 210 УК РФ. Банда - это 
всегда вооруженная устойчивая группа, в то время как преступное сообщество может не иметь ни одной единицы оружия, т.к. может создаваться для совершения таких преступлений, которые не требуют для их совершения применения оружия, например при совершении экономических преступлений.

Трудности при разграничении со ст. 210 вызывает и ст. 239 УК РФ (создание некоммерческой организации, посягающей на личность и права граждан). Применительно к ней можно заметить, что объективно данное преступление выражается в создании религиозного или общественного объединения, нередко во внешне законных формах. Соответственно, основные цели такого объединения преимущественно религиозные или общественные, но не откровенно преступные. Преступный характер таким объединениям придают насильственные и иные противоправные способы воздействия на их членов. Напротив, преступное сообщество не стремится к легализации своей деятельности (хотя это и не исключается), и его основные цели - совершение тяжких или особо тяжких преступлений для получения прямо или косвенно финансовой или иной материальной выгоды.

В данном случае, применительно к Республике Крым следует согласиться с мнением автора процессуально-публицистического издания о том, что «...За считанные годы бандитизм в Крыму развился, структурализовался, неразрывно сросся с бизнесом, пробился в политику, стал почти вровень с легитимной властью, частично переродился в «нормальный» бизнес и нормальную политику. Он явил образцы крайнего беспредела и глубокого «черного» порядка ... Пройдя все основные ступени и, наверное, впервые посерьезному, не слишком маскируясь (например, в национально-освободительные, националистические или религиозные одежды), крымский бандитизм бросил вызов всякой прочей власти».

Другим не менее важным вопросом является соотношение целей преступлений, предусмотренных ст. 210 и ст. 282.1 («Организация экстремистского сообщества»), ст. 282.2 («Организация деятельности экстремистской организации») УК РФ. Экстремистское сообщество (ст. 282.1 УК РФ), несмотря на свое название, также является типичной разновидностью организованной группы. Как верно указывает И.В. Сироткин, «терминологически экстремистское сообщество представляет собой разновидность преступного сообщества, предусмотренного ч. 4 ст. 35 УК РФ. Однако при изучении его определения в ст. 282.1 УК РФ можно установить, что оно таковым не является ввиду отсутствия признака сплоченности... В то же время в ч. 1 ст. 282.1 содержится указание на структурный характер экстремистского сообщества, а также сформулированное по аналогии со ст. 210 УК РФ положение об ответственности за создание объединения организаторов, руководителей или иных представителей частей или структурных подразделений такого сообщества в целях разработки планов и (или) условий для совершения преступлений экстремистской направленности. Подобная формулировка ст. 282.1 УК РФ приводит к абсолютному смешению понятий организованной группы и преступной организации».

Схожа ст. 210 УК РФ и с экстремистской организацией, о которой говорится в ст. 282.2 УК РФ. Она представляет собой общественное или религиозное объединение или иную организацию. Экстремистский характер придает этой организации наличие вступившего в законную силу решения о ликвидации или запрете деятельности в связи с осуществлением экстремистской деятельности. Для преступного сообщества не имеет большого значения его легальная регистрация в каких-либо организационно-правовых формах.

Проведенное научно-теоретическое исследование позволило выявить как общие, так и отличительные целевые признаки, присущие преступлениям, предусмотренным ст. $210,205.4,205.5,208,209,239,282.1$ и 282.2 Уголовного кодекса РФ и наглядно подтвердить, что помимо указанных в части 4 статьи 35 УК РФ целей совместного 
совершения одного или нескольких тяжких либо особо тяжких преступлений для получения прямо или косвенно финансовой или иной материальной выгоды, преступные сообщества на территории Республики Крым совершают преступления в целях посягательств на общественную безопасность и общественный порядок, жизнь и здоровье граждан, основы государственной власти, мир и безопасность человечества. Данное обстоятельство подтверждает ранее сделанный вывод о необходимости дополнения части 4 статьи 35 Уголовного кодекса РФ в части формулирования целей создания организованного преступного сообщества.

$$
* * *
$$

1. Кузнецова Н.Ф., Тяжкова И.М, Курс уголовного права. Т. 1 Преступление. Электронный ресурс // Режим доступа: http://www.studfiles.ru/preview/5834340/page:27. Дата обращения 01.06.2017.

2. Куфлева В.Н. Вопросы разграничения организации преступного сообщества (преступной организации) или участия в нем (ней) со смежными составами преступлений // Общество и право, 2015. № 1 (51). С. 89. (c 89-93)

3. Сироткин И. В. О совершенствовании уголовно-правовых норм об ответственности за создание, руководство и участие в организованных группах и преступных организациях // Вестн. Томск.гос. унта. 2008. Вып. 314. С. 127.

4. Суд присяжных: квалификация преступлений и процедура рассмотрения дел: научно-практическое пособие / Под.ред. А. В. Галаховой. М., 2006. С. 64.

5. Хижняк Д.С. О проекте стратегии противодействия транснациональной криминальной деятельности в Российской Федерации // Библиотека криминалиста. Научный журнал. 2016. № 6 (29). С. 17-30.

6. Чернецов К.Т. Крым бандитский. География - соучастница преступности. Часть 1. // Электронный pecypc: http://www.e-reading.club/chapter.php/29172/1/Chernecov_-_Krym_banditskiii.html. Дата обращения 18.05.2017.

\section{Пучкова В.В. \\ Смоленский филиал Международного юридического института}

Смоленский филиал Международного юридического института (Россия, Смоленск)

doi: $10.18411 / \mathrm{sr}-10-08-2017-12$

idsp: 000001:sr-10-08-2017-12

\section{Аннотация}

Актуальность темы обусловлена тем вниманием, которое в настоящее время руководством страны обращается на реализацию основополагающих конституционных прав граждан России, связанных с охраной здоровья. Цель статьи - проанализировать проблемы реализации статьи 27 Ф3 «Об основах охраны здоровья граждан». В статье анализируется конституционная обязанность граждан о соблюдении законодательства в сфере здравоохранения.

Ключевые слова: право на охрану здоровья; медицинская помощь; медицинские осмотры; обязанность о соблюдении законодательства; здравоохранение

\section{Annotation}

The relevance of the topic is due to the attention that the country's leadership is now turning to the implementation of the fundamental constitutional rights of Russian citizens related to health protection. The purpose of the article is to analyze the problems of implementation of Article 27 of the Federal Law "On the Fundamentals of Citizens' Health Protection". The article analyzes the constitutional duty of citizens to observe the legislation in the field of health care.

Key words: right to health protection; health care; Medical examinations; Obligation to comply with legislation; Health care 